Article

\title{
Genomic Loads and Genotypes of Respiratory Syncytial Virus: Viral Factors during Lower Respiratory Tract Infection in Chilean Hospitalized Infants
}

\author{
Yazmín Espinosa ${ }^{1, \dagger}$, Camila San Martín ${ }^{1, \dagger}$, Alejandro A. Torres ${ }^{2}$, Mauricio J. Farfán ${ }^{3}$, \\ Juan P. Torres ${ }^{3}$, Vasanthi Avadhanula ${ }^{4}$, Pedro A. Piedra ${ }^{4,5}$ and Lorena I. Tapia ${ }^{1,2, *}$ \\ 1 Department of Pediatrics and Pediatric Surgery, Hospital Roberto del Río, Facultad de Medicina, \\ Universidad de Chile, Profesor Zañartu 1085, Independencia, 8380418 Santiago, Chile; \\ y.espinosa.v@gmail.com (Y.E.); camilasanmartin@gmail.com (C.S.M.) \\ 2 Virology Program, Institute of Biomedical Sciences (ICBM), Facultad de Medicina, Universidad de Chile, \\ Independencia 1027, Pabellón J. Independencia, 8380453 Santiago, Chile; a.torres.riquelme@gmail.com \\ 3 Department of Pediatrics and Molecular Biology Laboratory, Hospital Luis Calvo Mackenna, \\ Facultad de Medicina, Universidad de Chile, Av. Antonio Varas 360, Providencia, 7500539 Santiago, Chile; \\ mfarfan@med.uchile.cl (M.J.F.); jptorres@med.uchile.cl (J.P.T.) \\ 4 Department of Molecular Virology and Microbiology, Baylor College of Medicine, One Baylor Plaza, \\ Room 248E, Houston, TX 77030, USA; avadhanu@bcm.edu (V.A.); ppiedra@bcm.edu (P.A.P.) \\ 5 Pediatrics, Baylor College of Medicine, One Baylor Plaza, Houston, TX 77030, USA \\ * Correspondence: ltapia@med.uchile.cl; Tel.: +562-273-71047 \\ + These authors contributed equally to this work.
}

Academic Editor: Susanna Esposito

Received: 30 December 2016; Accepted: 13 March 2017; Published: 21 March 2017

\begin{abstract}
The clinical impact of viral factors (types and viral loads) during respiratory syncytial virus (RSV) infection is still controversial, especially regarding newly described genotypes. In this study, infants with RSV bronchiolitis were recruited to describe the association of these viral factors with severity of infection. RSV antigenic types, genotypes, and viral loads were determined from hospitalized patients at Hospital Roberto del Río, Santiago, Chile. Cases were characterized by demographic and clinical information, including days of lower respiratory symptoms and severity. A total of 86 patients were included: 49 moderate and 37 severe cases. During 2013, RSV-A was dominant (86\%). RSV-B predominated in 2014 (92\%). Phylogenetic analyses revealed circulation of GA2, Buenos Aires (BA), and Ontario (ON) genotypes. No association was observed between severity of infection and RSV group $(p=0.69)$ or genotype $(p=0.87)$. After a clinical categorization of duration of illness, higher RSV genomic loads were detected in infants evaluated earlier in their disease $(p<0.001)$ and also in infants evaluated later, but coursing a more severe infection $(p=0.04)$. Although types and genotypes did not associate with severity in our children, higher RSV genomic loads and delayed viral clearance in severe patients define a group that might benefit from new antiviral therapies.
\end{abstract}

Keywords: respiratory syncytial virus; RSV genotypes; viral load; severity

\section{Introduction}

Respiratory syncytial virus (RSV) is the most common cause of lower respiratory tract infection (LRTI) in children [1] and an important agent in the elderly and immunocompromised patients [2], generating a global public health problem [3]. In Chile, RSV is the cause of important outbreaks each winter, accounting for a high number of outpatient visits and hospitalizations [4]. Actual treatment 
is mainly supportive [5,6] and although an immunoprophylactic therapy (palivizumab, Synagis ${ }^{\circledR}$, MedImmune, Inc., Gaithersburg, MD, USA) has been approved for infants at high risk of severe infection [7], most hospitalized RSV infected infants do not meet the criteria for immunoprophylaxis. Moreover, a high-risk condition is not present in approximately $65 \%$ of RSV hospitalized infants [1], making it difficult to predict who will develop a severe disease. The pathogenesis of RSV remains the topic of intense basic and clinical research with emphasis on the host (genetic and immunologic), viral, and environmental factors in relation to severity of infection.

RSV has been classified into groups A and B based on antigenic differences of the G, F, and N proteins [8]. Further genetic analysis of the nucleotide sequence of the second hypervariable region on the $G$ gene allowed for the classification into genotypes within antigenic groups RSV-A and B $[9,10]$. Many studies have reported the molecular epidemiology and genetic variability of RSV worldwide [10-20], revealing the emergence and spread of new genotypes with duplication of $\sim 60$ to 70 nucleotides in this G hypervariable region for RSV-A (RSV Ontario) and RSV-B (RSV Buenos Aires) $[15,19,21,22]$. Although none of the variants or genotypes has been consistently associated with greater virulence or pathogenicity $[13,18,22,23]$, some recent reports describing clinical aspects of contemporary genotypes (NA1 and ON1) have shown higher frequencies of LRTI and hospitalizations rates [24-26].

Another viral factor that has been explored as determinant of respiratory disease severity is the viral load in the respiratory tract. Some studies have detected a correlation between RSV loads and the disease severity in hospitalized infants $[27,28]$, and others have reported that higher viral loads predict longer durations of hospitalizations $[29,30]$. The latest was recently confirmed by a multicenter prospective cohort including 1764 children with RSV bronchiolitis [31]. Thus, early intervention with antiviral therapies initiated at the time of highest viral replication (approximately at the third to fifth day of symptoms) could improve the prognosis of the disease, directly reducing the viral cytopathic effects and inflammatory response [30].

The aim of this study was to describe molecular viral factors: RSV group, genotype, and viral genomic loads in Chilean infants during two consecutive RSV epidemics (2013 and 2014) and explore their relationship with severity of disease.

\section{Results}

\subsection{Patients and Clinical Severity}

A total of 90 hospitalized infants with RSV LRTI were recruited, 40 cases during the 2013 outbreak and 50 during the 2014 outbreak in Santiago. We excluded four immunofluorescence assay IFA positive RSV cases because they could not be confirmed by Q-PCR. Thus, data from 86 infants were available for the analysis. The median age was 73.7 (14-247) days and 54.6\% were male. Based on the clinical score, 49 infants were determined to have moderate and 37 severe disease, with similar frequencies between the 2013 and 2014 epidemic outbreaks $(p=0.63)$. In Table 1, demographics, medical history, and clinical characteristics by severity of the infection are presented. No significant differences were found in age, gender, or medical history. Length of stay, requirement of supplemental oxygen, $\mathrm{FiO}_{2}>30 \%$, and mechanical ventilation were significantly higher in the severe group.

\subsection{Viral Diagnosis}

RSV was the only pathogen detected in 66 cases $(76.7 \%)$, and coinfection was observed in 20 patients $(23.3 \%)$. The coinfection patterns were: 16 cases with RSV-human rhinovirus (HRV) (80\%); 2 cases with RSV-coronavirus (CoV) HKU1 (10\%), 1 case with RSV-parainfluenza virus type 3 (PIV3) (5\%), and 1 case with RSV-HRV-bocavirus (5\%). No significant associations were found between demographics or clinical features and coinfection (Table 2). Nevertheless, it was observed that coinfection was more frequent in patients with a family history of asthma or atopy $(p=0.017)$. 
Table 1. Demographic characteristics, medical history, and clinical features of infants with moderate and severe RSV infection.

\begin{tabular}{|c|c|c|c|}
\hline Patients Characteristics & $\begin{array}{l}\text { Moderate RSV Infection } \\
\qquad(n=49)\end{array}$ & $\begin{array}{l}\text { Severe RSV Infection } \\
\qquad(n=37)\end{array}$ & $p$-Value \\
\hline Gender (\% male) & 46.9 & 64.8 & $0.1^{\mathrm{a}}$ \\
\hline Age (days) ${ }^{b}$ & $52(14-242)$ & $55(15-247)$ & $0.5^{c}$ \\
\hline \multicolumn{4}{|l|}{ Medical history } \\
\hline Breastfeeding $(\%)^{\mathrm{d}}$ & 91.8 & 91.9 & $0.99^{\mathrm{a}}$ \\
\hline Personal atopic history (\%) & 6.1 & 2.7 & $0.46^{\mathrm{a}}$ \\
\hline Family history of asthma or atopy (\%) & 18.4 & 24.3 & $0.5^{\mathrm{a}}$ \\
\hline Maternal smoking (\%) & 22.5 & 32.4 & $0.3^{\mathrm{a}}$ \\
\hline Indoor smoke (\%) $\mathrm{e}^{\prime}$ & 48.9 & 64.9 & $0.14^{\mathrm{a}}$ \\
\hline Siblings $\left(\mathrm{n}^{\circ}\right)^{\mathrm{b}}$ & $1.35(0-6)$ & $1.03(0-5)$ & $0.13^{c}$ \\
\hline \multicolumn{4}{|l|}{ Clinical features } \\
\hline Length of stay (days) ${ }^{b}$ & $4.04(2-11)$ & $9.62(4-36)$ & $<0.001^{\mathrm{c}}$ \\
\hline Supplemental oxygen requirement (\%) & 85.7 & 100 & $0.02^{\mathrm{a}}$ \\
\hline $\mathrm{FiO}_{2}>30 \%(\%)$ & 6.1 & 45.9 & $<0.001^{\text {a }}$ \\
\hline Mechanical ventilation (\%) & 0 & 10.8 & $0.02^{\mathrm{a}}$ \\
\hline
\end{tabular}

RSV, respiratory syncytial virus; ${ }^{a} X^{2}$ test; ${ }^{b}$ Median (Min-Max); ${ }^{c}$ Mann-Whitney Rank Sum Test; ${ }^{d}$ Breastfeeding at the moment of hospitalization; ${ }^{\mathrm{e}}$ Indoor smoking or combustion heating (wood, kerosene).

Table 2. Clinical characteristics and medical history of infants with RSV lower respiratory tract infection (LRTI) as a single infection and coinfection.

\begin{tabular}{|c|c|c|c|}
\hline Patients Characteristics & RSV Single Infection $(n=66)$ & RSV + Other Virus $(n=20)$ & $p$-Value \\
\hline \multicolumn{4}{|l|}{ Clinical data: } \\
\hline Age (days) ${ }^{a}$ & $52(14-247)$ & $74.5(17-242)$ & $0.08^{\mathrm{b}}$ \\
\hline Severe infection $(\%)$ & 48.5 & 25 & $0.063^{c}$ \\
\hline Length of hospitalization (days) ${ }^{a}$ & $6(2-36)$ & $4(2-17)$ & $0.2^{\mathrm{b}}$ \\
\hline \multicolumn{4}{|l|}{ Medical history: } \\
\hline Personal atopic history (\%) & 3.03 & 10 & $0.195^{\mathrm{c}}$ \\
\hline Maternal smoking (\%) & 25.8 & 30.0 & $0.71^{\mathrm{c}}$ \\
\hline Indoor smoke $(\%)^{d}$ & 57.6 & 50 & $0.55^{\mathrm{c}}$ \\
\hline Familiar asthma or atopic history (\%) & 15.1 & 40 & $0.017^{\mathrm{c}}$ \\
\hline
\end{tabular}

\subsection{RSV Groups and Genotypes}

Antigenic groups RSV-A ( $n=36)$ and RSV-B $(n=50)$ were detected, showing different circulation frequencies when comparing the two epidemic seasons $(p<0.01)$. As shown in Figure $1 \mathrm{~A}$, during the 2013 outbreak, RSV-A strains were dominant with a frequency of $86 \%(n=32)$. In contrast, during 2014 the major group was RSV-B, found in $92 \%(n=45)$ of patients. No difference in the severity of the infection was detected between antigenic groups (Figure $1 \mathrm{~B}, p=0.69$ ). Moreover, no significant correlation was found between RSV groups and severity (Spearman's rho $=-0.04 ; p=0.70$ ).

Genotype determination was performed on 55 samples $(64 \%)$. Sequenced viruses in RSV-A clustered with reference viruses in genotypes GA2 $(n=6)$ and ON $(n=17)$ (Supplementary Figure S1). All RSV-B viruses clustered with reference viruses in genotype BA $(n=32)$, as shown in Supplementary Figure S2. We found no difference in disease severity between GA2, ON, and BA genotype (Figure 1C, $p=0.87$ ) with no significant correlation (Spearman's $r h o=-0.07 ; p=0.61$ ). 
A

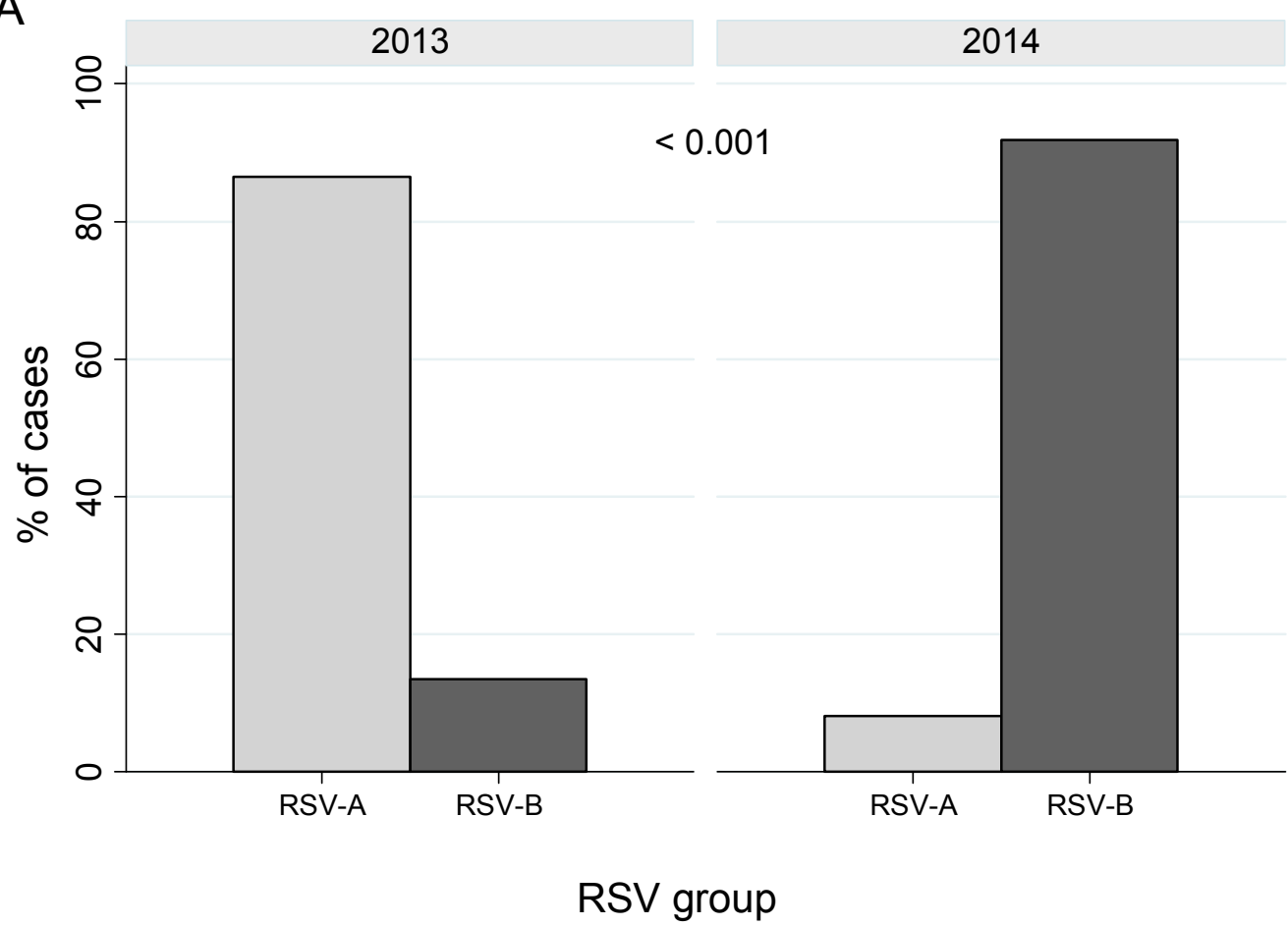

B

Spearman's rho $=-0.04 ; p=0.70$

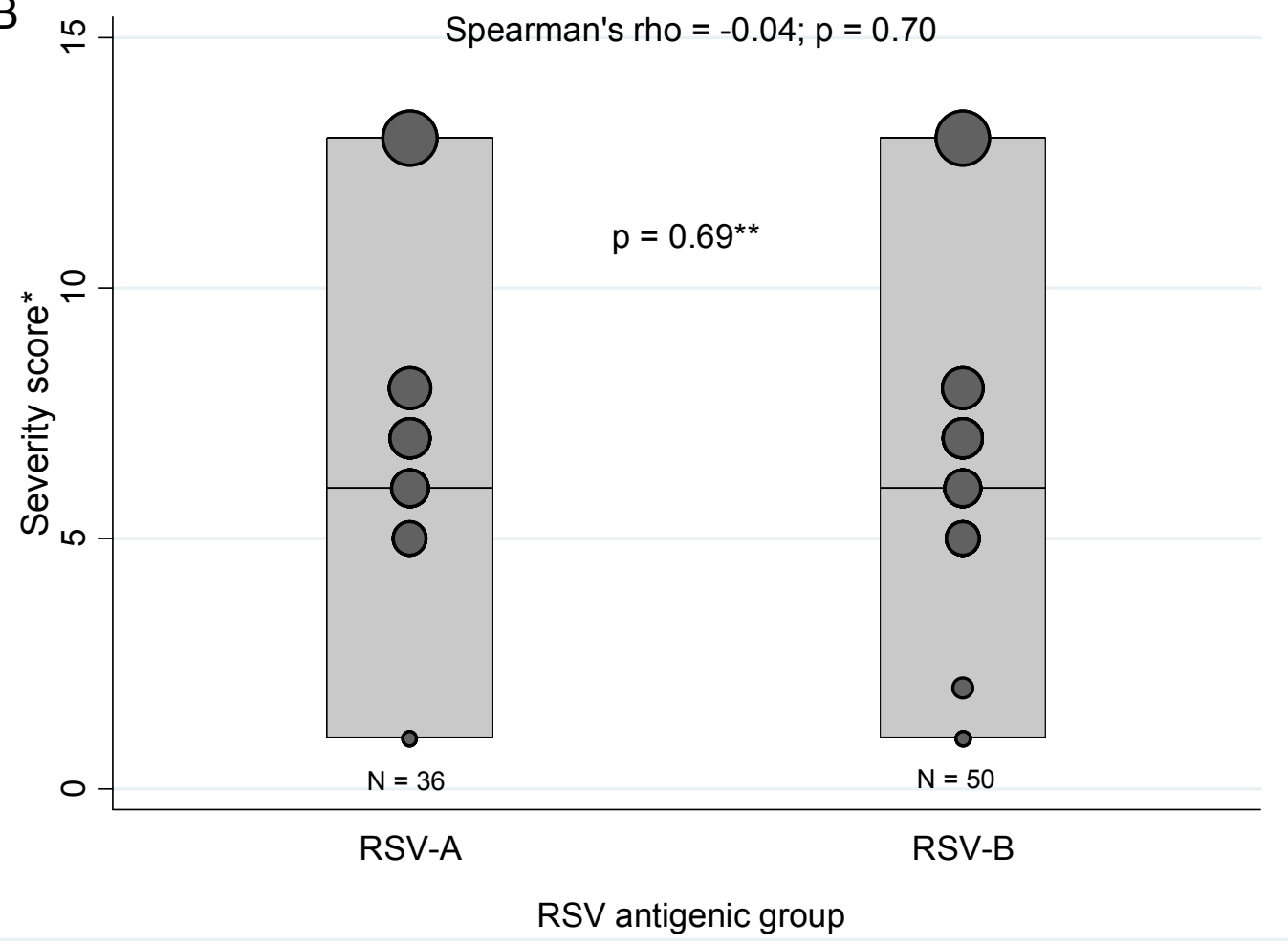

Figure 1. Cont. 


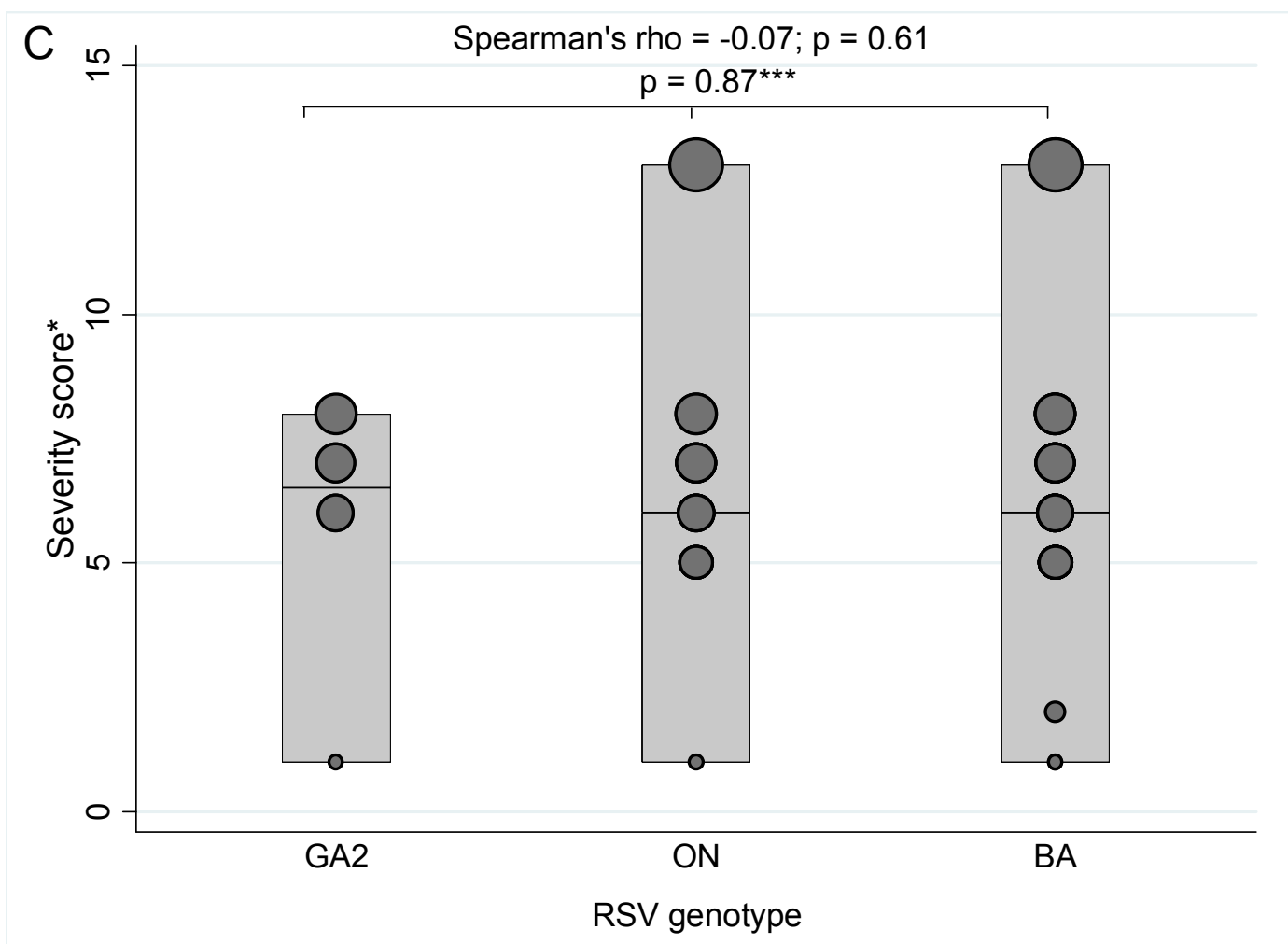

Figure 1. RSV antigenic groups and genotypes detected in hospitalized infants with LRTI. (A) RSV antigenic groups detected during 2013 and 2014 epidemic outbreaks in Santiago, Chile; (B) Severity of the infection by antigenic groups: Median, Minimum, and Maximum values are represented in bars. Scatter plot with weighted markers is shown with circles; (C) Severity of infection by genotypes (ON: Ontario; BA: Buenos Aires): Median, Minimum, and Maximum values are represented in bars. Scatter plot with weighted markers is shown with circles. * Severity score by Larrañaga et al., 2009 [32].

** Mann-Whitney test. ${ }^{* * *}$ Kruskal-Wallis test.

\subsection{Respiratory Syncytial Virus (RSV) Genomic Loads}

A significant difference in viral genomic load was not detected between RSV infected infants having RSV as the sole infection or as a coinfection $(6.18 \pm 1.18$ vs. $6.12 \pm 1.01 \log 10$ copies $/ \mathrm{mL}$; $p=0.41)$. Interestingly, a significant difference in the respiratory viral genomic load was detected between the RSV antigenic groups (Figure 2A; $p=0.037$ ). RSV-B infected infants had a higher median viral genomic load $(6.36 \pm 1.14 \log 10$ copies $/ \mathrm{mL})$ than RSV-A $(5.91 \pm 1.10 \log 10 \mathrm{copies} / \mathrm{mL})$ infected infants. Although higher viral genomic loads were detected in nasal secretions of severe cases $(6.34 \pm 1.19$ vs. $6.04 \pm 1.09 \log 10$ copies $/ \mathrm{mL})$, the difference was not statistically significant (Figure 2B, $p=0.12)$.

Viral genomic loads were also analyzed by the duration of the LRTI at the time of sampling. As illustrated in Figure 3A, significantly higher viral genomic loads were found in infants with 3 days or less of lower respiratory tract symptoms compared to those with more than 3 days $(p<0.001)$. Thus, higher viral loads were detected in the RSV infected infants with an earlier LRTI presentation $(6.44 \pm 1.09$ vs. $5.52 \pm 0.98 \log 10$ copies $/ \mathrm{mL})$. Finally, analyzing the stage ( $\leq 3$ days, $>3$ days $)$ of LRTI presentation by severity of infection (Figure 3B), we found that viral genomic loads at day 3 or less of LRTI were comparable between moderate and severe LRTI (6.42 \pm 0.97 vs. $6.45 \pm 1.24 \log 10$ copies $/ \mathrm{mL}$; $p=0.45$ ), however, in the later LRTI stage ( $\geq 3$ days) the infants with severe RSV LRTI had significantly higher viral genomic loads (5.26 \pm 0.92 vs. $5.98 \pm 0.95 \log 10$ copies $/ \mathrm{mL} ; p=0.04)$. 


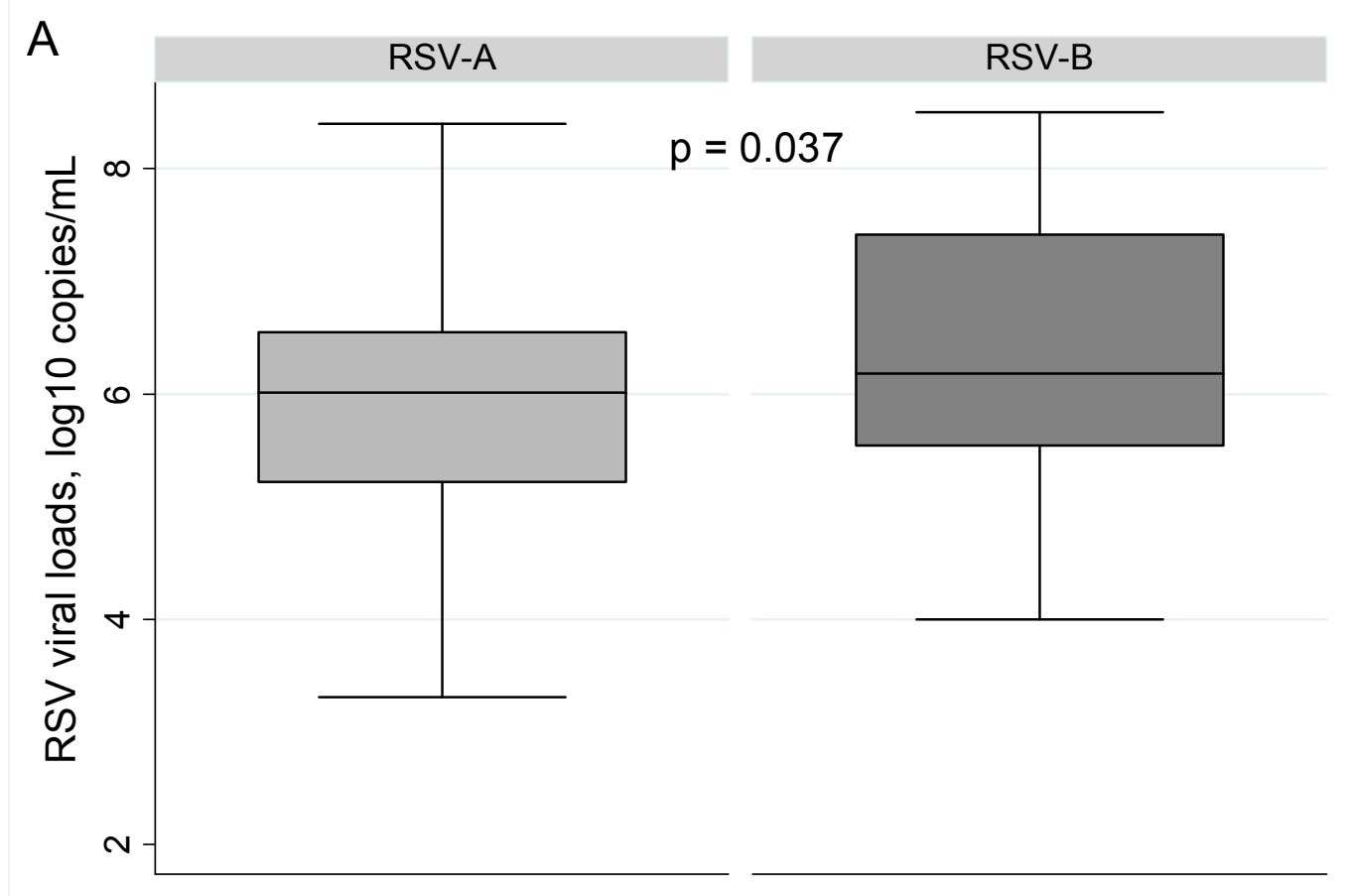

B

Boderate RSV

Severe RSV

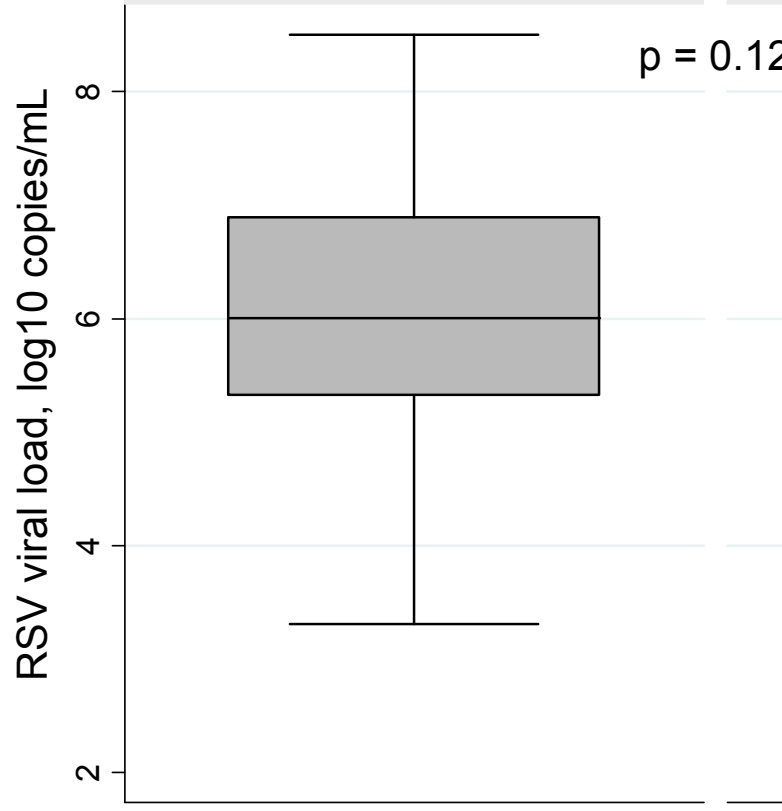

Figure 2. RSV genomic loads detected in hospitalized infants with LRTI. (A) Viral loads by RSV antigenic groups; (B) Viral loads by the severity of the infection. 


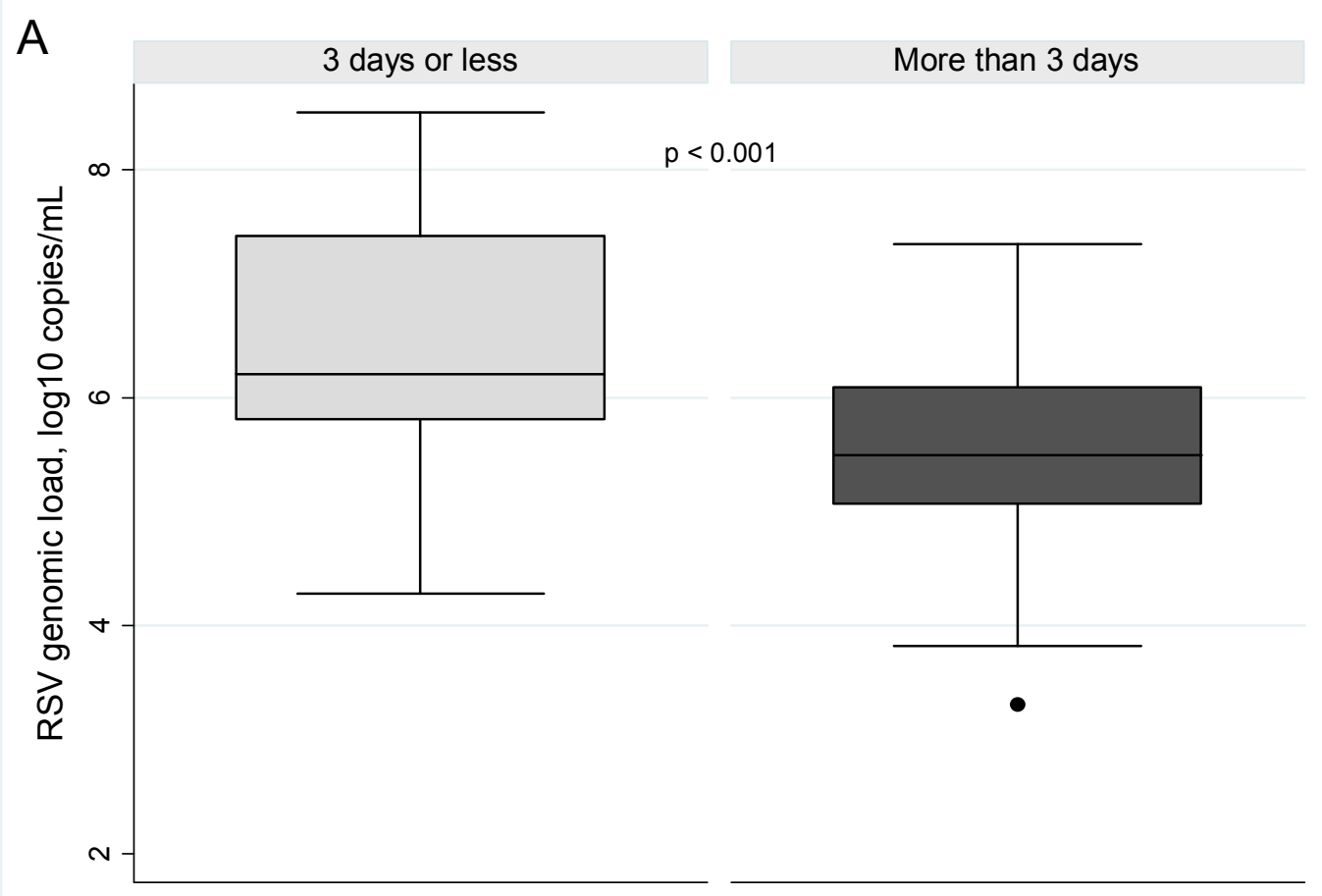

B

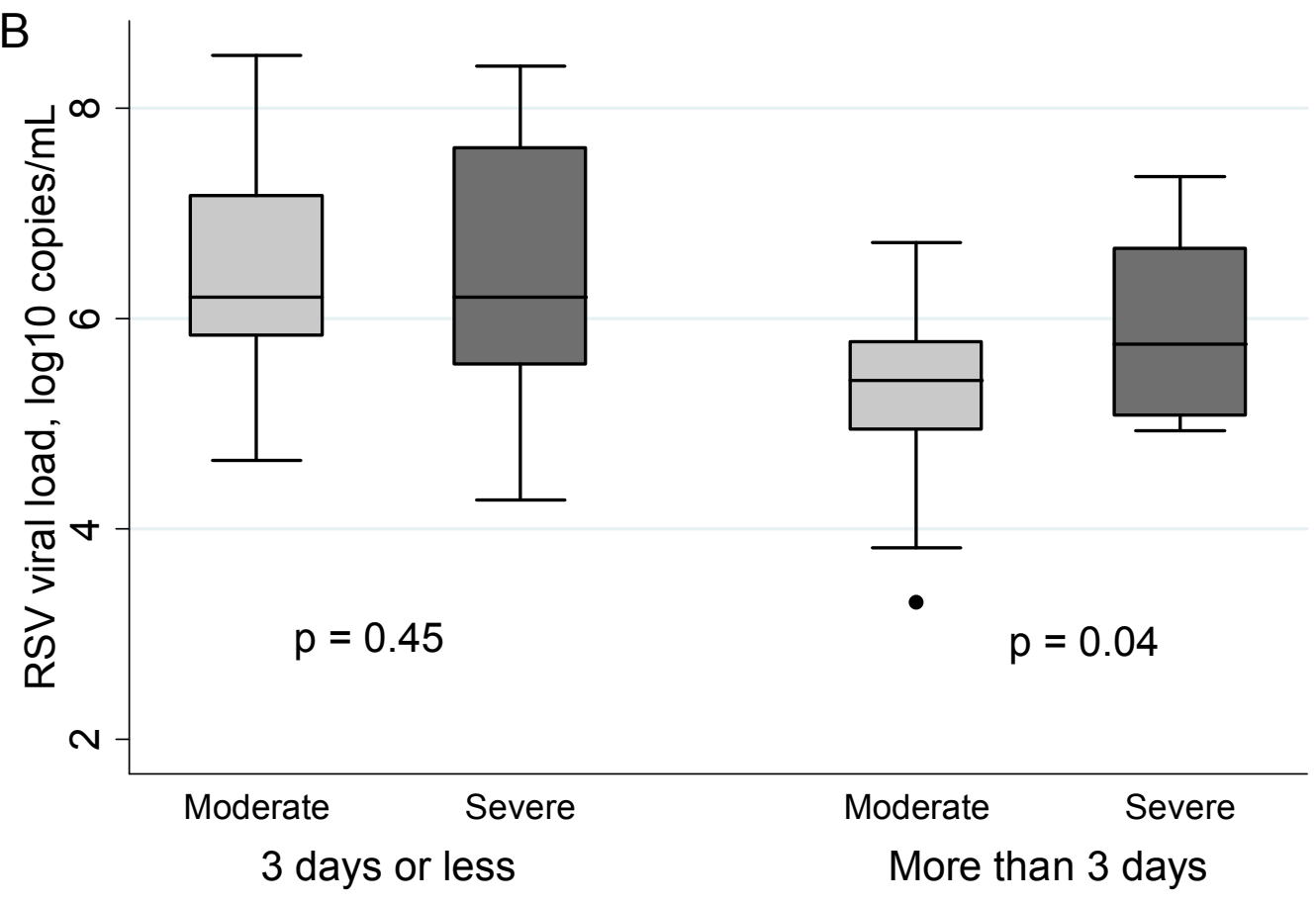

(Days of lower respiratory symptoms at time of sampling)

Figure 3. RSV genomic loads detected in hospitalized infants with LRTI by duration of lower respiratory symptoms at the time of sampling. (A) Viral loads in patients with early (3 days or less of lower symptoms) and late (more than 3 days of symptoms) RSV infection; (B) Viral loads in patients with early and late illness according to the severity of RSV infection. 
Independent viral factors of RSV disease severity were explored by bivariate (Table 3) and multivariate analyses. RSV antigenic group, genotype, or viral genomic load did not predict severity of infection. A higher odds ratio, although not statistically significant, was detected when the RSV genomic load was analyzed with respect to the duration and severity of the LRTI with a higher viral genomic load in infants with longer duration of severe LRTI $(\mathrm{OR}=2.51, p=0.09)$. This association did not change when adjusted by age, gender, and RSV type (data not shown).

Table 3. Demographics, viral types, and viral loads as independent factors predicting severity in infants with RSV infection.

\begin{tabular}{ccc}
\hline & Severe RSV Infection & \\
\hline Independent factors & OR (95\% CI) & $p$-Value \\
\hline Male gender & $2.09(0.87-5.02)$ & 0.1 \\
Age (days) & $1.00(0.99-1.00)$ & 0.59 \\
RSV antigenic type & $1.10(0.46-2.62)$ & 0.82 \\
RSV genotype ${ }^{\mathrm{a}}$ & $1.07(0.26-4.28)$ & 0.93 \\
GA2 & $1.07(0.38-3.06)$ & 0.89 \\
ON & $1.19(0.50-2.80)$ & 0.68 \\
BA & & 0.23 \\
RSV genomic loads & $1.26(0.86-1.86)$ & 0.90 \\
All cases $(n=86)$ & $1.02(0.65-1.63)$ & 0.09 \\
Early disease ${ }^{\mathrm{b}}(n=61)$ & $2.51(0.85-7.41)$ &
\end{tabular}

RSV, respiratory syncytial virus; OR: odds ratio; CI: confidence interval; ON: Ontario; BA: Buenos Aires; ${ }^{\text {a }}$ Reference value $=$ "other genotypes"; ${ }^{b}$ Early disease: 3 days or less of lower respiratory symptoms; ${ }^{\mathrm{c}}$ Late disease: more than 3 days of lower respiratory symptoms.

\section{Discussion}

Recent promising reports on the development of drug therapeutics for RSV have been published $[33,34]$ in response to a critical medical need for the care of infants with moderate to severe RSV illness. In parallel, molecular virology has enhanced our ability to dissect the viral contribution to the severity of the disease. However, many questions remain unclear about the direct role of RSV in airway injury and clinical outcome. In this study, we present evidence about viral factors-RSV group, genotype, and viral genomic load — that might affect the course and severity of the disease.

Circulation of RSV in Santiago de Chile has been reported by Avendaño et al. [4], who described cocirculation of RSV-A and RSV-B antigenic groups with dominance of A in alternate years. They also described that epidemics appeared earlier and of greater intensity when RSV-B dominated. Our results in two consecutive years showed this alternating antigenic pattern, with RSV-A being dominant during 2013 and RSV-B in 2014. Moreover, as reported by the Institute of Public Health (ISP) in Chile [35], an earlier RSV epidemic occurred in 2014, when viruses in the RSV-B group were the major circulating RSV.

No association of the antigenic group (A or B) with severity of the disease was observed in our study, which is in agreement with the majority of the publications in this area.

Regarding RSV genotypes, as expected and according to the global transmission dynamics described by Duvvuri et al. [19], the recently described RSV-A Ontario genotype [15] was detected in our population since 2013, replacing all RSV-A samples collected in 2014. For RSV-B, only BA genotype was identified. In our hospitalized patients, no association was found between the circulating genotypes (GA2, ON, BA) with the severity of the lower respiratory tract disease. In contrast to recent reports [24-26], the recently described ON genotype did not show a higher severity score. As with the influenza virus, continuous surveillance may be needed to detect new emergent genotypes and to assess their immediate effect in susceptible populations. We have recently described that genetic variations are present in the three RSV surface proteins [16], including not only G protein, but also the 
fusion (F) protein, which is the major determinant for the host's immune response, and the main target for antiviral therapy and vaccination strategies [36]. Some of these genomic variations in the viral genome might impact the pathogenic process and the disease, and thus need to be explored beyond genotype classification.

In our study, a relationship between coinfection with other viruses and severity was not detected when compared to infants with sole RSV infection. Moreover, there was a trend, although not significant, for less severe RSV disease with the presence of coinfection with other viral agents $(p=0.063)$. This finding may be explained, in part, by the older age of the coinfected group ( 74.5 vs. 52 days; $p=0.08$ ), but it is also relevant that $80 \%$ of these patients had RSV-HRV infection. It has been shown that infants with HRV bronchiolitis are older, and more likely to have asthma-like characteristics [37-39], which is also in agreement with the association detected with family history of asthma or atopy in our group with RSV coinfection.

Recent publications have described associations between RSV loads and severity scores [40,41], duration of hospitalization [30,31], and Intensive Care Unit requirements [30]. Moreover, analyzes considering the days of symptoms prior to sample collection have shown that viral clearance is an important factor to consider [30,41], since significant differences are detected in genomic loads and their predictive capacity of severity depending on the date of sampling. In our study, we confirmed that a greater number of RSV genomic copies are found when sampling occurs early during the LRTI, being significantly lower when the samples are collected later than 3 days of onset of cough, the symptom we chose as a marker of LRTI. In agreement with the studies by Zhou et al. [41] and El Saleeby et al. [30], we found higher viral loads in the infants with severe LRTI with more than 3 days of lower respiratory tract symptoms, but not in infants with severe LRTI at 3 days or less of illness, suggesting a difference in the kinetics of viral clearance. We postulate that a delayed viral clearance is contributing to greater airway injury and longer duration of severe LRTI. Although the main limitation in this study is the lack of sequential samples from our patients, we believe that the data reported complements the limited information collected by other authors. We propose a simple clinical approach with cough as a marker to characterize a population that may benefit from possible future therapeutic approaches. The data presented in relation to genotypes and viral loads should drive further exploration of viral evolution and viral dynamics during primary RSV infection and its relation to severity.

\section{Materials and Methods}

An Observational, Analytical, Cross-Sectional Study Was Performed.

\subsection{Patients}

By consecutive sampling, infants under 1 year of age who presented with their first community-acquired RSV LRTI were enrolled after obtaining parental (legal guardian) written informed consent. They were hospitalized at Hospital Roberto del Río in Santiago de Chile, during winter outbreaks (May to September) of 2013 and 2014. Inclusion criteria were: first documented episode of acute LRTI, a positive direct immunofluorescence assay for RSV (performed at HRR central laboratory at admission), and enrollment into the study within the first $72 \mathrm{~h}$ of hospital admission. Infants with possible bacterial infection, prematurity ( $<37$ weeks gestational age), immunodeficiency, and documented chronic lung or heart diseases were excluded.

\subsection{Samples}

A single nasopharyngeal aspirate (NPA) sample was obtained according to the standard of respiratory care. The samples were refrigerated and transported to the Virology Laboratory during the day of collection and were divided into aliquots in order to perform viral diagnostic confirmation, genotype analysis, and viral genomic load quantification. 


\subsection{Demographic and Clinical Characteristics}

Demographic and clinical data were collected by a structured interview with the parents or legal guardians at enrollment. The date of onset of lower respiratory symptoms (defined by the day the cough started) and the duration of lower respiratory disease at the time of sampling were also registered. In addition, after discharge from the hospital, data from the medical records were extracted and used to determine the severity of the illness, moderate or severe, based on a previously published clinical score [32].

\subsection{Viral Diagnosis and Determination of RSV Genomic Load}

Singleplex or duplex 2-step real time PCR assays and analyses were performed at the laboratories of L.I.T and P.A.P using primers and probes that have been previously described [42-44]. Real time reverse transcription-PCR (Q-PCR) was used to detect RNA viruses, including: RSV-A and RSV-B; human rhinovirus (HRV), coronaviruses (CoV) NL-63, HKU1, OC43, and 229E; parainfluenza virus (PIV) types 1, 2, and 3; influenza virus types A, B, and 2009 A (H1N1); human metapneumovirus (HMPV). Real time-PCR was performed for the detection of DNA pathogens including adenovirus, bocavirus, Mycoplasma pneumoniae, and Bordetella pertussis. Viral genomic loads for RSV positive samples were determined at the laboratory of P.A.P by Q-PCR. Threshold cycle (CT) values were determined, thereby providing a semiquantitative measure of viral genomic load, as previously described [45].

\subsection{RSV Genotype Determination}

Amplification of the second hypervariable region of the $G$ gene was performed using primers and conditions of PCR reactions as previously described [16]. PCR products were purified and sent for sequencing by Sanger method at Macrogen Inc. (Seoul, Korea). Chromatogram traces were visualized with BioEdit Sequence Alignment Editor Version 7.0.9.0 [46] to confirm the quality score. For contig assembling, SeqMan ${ }^{\circledR}$ program of Lasergene 8 program suite (DNASTAR, Inc., Madison, WI, USA) was used, obtaining the $G$ gene sequence for each strain. A fragment of $\sim 270$ to $330 \mathrm{bp}$ located in the second hypervariable region of the $\mathrm{G}$ gene was obtained. Based on the methodology described by Peret et al. [9], phylogenetic analyses were performed with $\mathrm{R}$ software ( $\mathrm{R}$ Development Core Team, 2009) including our sequences and reference sequences retrieved from Genbank [9-12,14,47-49]. RSV group and genotype categorization was achieved based on the clustering and distribution within the phylogenetic tree $[9,16]$.

\subsection{Statistical Analysis}

Demographic and clinical characteristics were described using frequencies in the case of categorical variables, and measures of central tendency and dispersion for continuous variables. Comparisons between groups were performed using $\chi^{2}$, Mann-Whitney Rank Sum, or Kruskal Wallis tests as appropriate. A $p$-value of $<0.05$ was considered statistically significant. Spearman correlation test was used to analyze relationship between viral types and severity. The association between clinical severity and independent variables was assessed by $\chi^{2}$ tests and logistic regression analysis.

\subsection{Ethics}

This FONCECYT study $\mathrm{N}^{\circ} 11121536$ was approved by the Local Ethics Committee of the North Metropolitan Health Service (25 October 2012) and the Faculty of Medicine, Universidad de Chile (28 June 2012). Informed consent was signed by the parents of all study participants.

\section{Conclusions}

Although neither the RSV antigenic group nor the genotypes were associated with clinical severity, a delayed viral clearance might be associated with greater airway injury and thus disease severity. 
New antiviral drug therapies hold the promise of shortening the clearance of RSV in the respiratory tract and thus might mitigate severity of disease.

Supplementary Materials: Supplementary materials can be found at www.mdpi.com/1422-0067/18/3/654/s1.

Acknowledgments: This work was supported by Fondo Nacional de Ciencia y Tecnología (FONDECYT) (Initiation into Research Grant No. 11121536 and Regular Grant No. 1130911); and SAVAL Funding for Research 2014. The authors thank all physicians and nurses who helped with the recruitment of patients, especially to Matías Echeverría and Fernando Eimbcke. Additionally, the authors wish to thank Monica Peña and María Inés Espinoza for their technical assistance.

Author Contributions: Lorena I. Tapia, Yazmin Espinosa, Camila San Martín, and Juan P. Torres conceived and designed the study; Lorena I. Tapia, Yazmin Espinosa, and Camila San Martín recruited patients and collected data; Lorena I. Tapia, Alejandro A. Torres, Mauricio J. Farfán, and Vasanthi Avadhanula performed the experiments; Lorena I. Tapia, Yazmin Espinosa, Camila San Martín, Mauricio J. Farfán, Juan P. Torres, and Pedro A. Piedra analyzed the data; Pedro A. Piedra, Mauricio J. Farfán, and Juan P. Torres contributed reagents/materials/analysis tools; Lorena I. Tapia, Yazmin Espinosa, Camila San Martín, Pedro A. Piedra, Vasanthi Avadhanula, and Juan P. Torres wrote the paper.

Conflicts of Interest: The authors declare no conflict of interest.

\section{References}

1. Hall, C.B.; Weinberg, G.A.; Iwane, M.K.; Blumkin, A.K.; Edwards, K.M.; Staat, M.A.; Auinger, P.; Griffin, M.R.; Poehling, K.A.; Erdman, D.; et al. The burden of respiratory syncytial virus infection in young children. N. Engl. J. Med. 2009, 360, 588-598. [CrossRef] [PubMed]

2. Falsey, A.R.; Hennessey, P.A.; Formica, M.A.; Cox, C.; Walsh, E.E. Respiratory syncytial virus infection in elderly and high-risk adults. N. Engl. J. Med. 2005, 352, 1749-1759. [CrossRef] [PubMed]

3. Nair, H.; Nokes, D.J.; Gessner, B.D.; Dherani, M.; Madhi, S.A.; Singleton, R.J.; O'Brien, K.L.; Roca, A.; Wright, P.F.; Bruce, N.; et al. Global burden of acute lower respiratory infections due to respiratory syncytial virus in young children: A systematic review and meta-analysis. Lancet 2010, 375, 1545-1555. [CrossRef]

4. Avendaño, L.F.; Palomino, M.A.; Larranaga, C. Surveillance for Respiratory Syncytial Virus in Infants Hospitalized for Acute Lower Respiratory Infection in Chile (1989 to 2000). J. Clin. Microbiol. 2003, 41, 4879-4882. [CrossRef] [PubMed]

5. Ralston, S.L.; Lieberthal, A.S.; Meissner, H.C.; Alverson, B.K.; Baley, J.E.; Gadomski, A.M.; Johnson, D.W.; Light, M.J.; Maraqa, N.F.; Mendonca, E.A.; et al. Clinical Practice Guideline: The Diagnosis, Management, and Prevention of Bronchiolitis. Pediatrics 2014, 134, e1474-e1502. [CrossRef] [PubMed]

6. Ingelfinger, J.R.; Meissner, H.C. Viral Bronchiolitis in Children. N. Engl. J. Med. 2016, 374, 62-72.

7. American Academy of Pediatrics. Updated guidance for palivizumab prophylaxis among infants and young children at increased risk of hospitalization for respiratory syncytial virus infection. Pediatrics 2014, $134,415-420$.

8. Anderson, L.J.; Hierholzer, J.C.; Tsou, C.; Hendry, R.M.; Fernie, B.F.; Stone, Y.; Mcintosh, K. Antigenic Characterization of Respiratory Syncytial Virus Strains with Monoclonal Antibodies. J. Infect. Dis. 1985, 151, 626-633. [CrossRef] [PubMed]

9. Peret, T.C.; Hall, C.B.; Schnabel, K.C.; Golub, J.A.; Anderson, L.J. Circulation patterns of genetically distinct group A and B strains of human respiratory syncytial virus in a community. J. Gen. Virol. 1998, 79, 2221-2229. [CrossRef] [PubMed]

10. Peret, T.C.; Hall, C.B.; Hammond, G.W.; Piedra, P.A.; Storch, G.A.; Sullender, W.M.; Tsou, C.; Anderson, L.J. Circulation patterns of group $A$ and $B$ human respiratory syncytial virus genotypes in 5 communities in North America. J. Infect. Dis. 2000, 181, 1891-1896. [CrossRef]

11. Galiano, M.C.; Palomo, C.; Videla, C.M.; Arbiza, J.; Melero, A.; Carballal, G. Genetic and Antigenic Variability of Human Respiratory Syncytial Virus (Groups A and B) Isolated over Seven Consecutive Seasons in Argentina (1995 to 2001). J. Clin. Microbiol. 2005, 43, 2266-2273. [CrossRef] [PubMed]

12. Venter, M.; Madhi, S.A.; Tiemessen, C.T.; Schoub, B.D. Genetic diversity and molecular epidemiology of respiratory syncytial virus over four consecutive seasons in South Africa: Identification of new subgroup A and B genotypes. J. Gen. Virol. 2001, 82, 2117-2124. [CrossRef] [PubMed] 
13. Zlateva, K.T.; Vijgen, L.; Dekeersmaeker, N.; Naranjo, C.; Van Ranst, M. Subgroup prevalence and genotype circulation patterns of human respiratory syncytial virus in Belgium during ten successive epidemic seasons. J. Clin. Microbiol. 2007, 45, 3022-3030. [CrossRef] [PubMed]

14. Zlateva, K.T.; Lemey, P.; Moe, E.; Vandamme, A.; Ranst, M. Van Genetic Variability and Molecular Evolution of the Human Respiratory Syncytial Virus Subgroup B Attachment G Protein. J. Virol. 2005, 79, 9157-9167. [CrossRef] [PubMed]

15. Eshaghi, A.; Duvvuri, V.R.; Lai, R.; Nadarajah, J.T.; Li, A.; Patel, S.N.; Low, D.E.; Gubbay, J.B. Genetic variability of human respiratory syncytial virus a strains circulating in ontario: A novel genotype with a 72 nucleotide G gene duplication. PLoS ONE 2012, 7, e32807. [CrossRef] [PubMed]

16. Tapia, L.I.; Shaw, C.A.; Aideyan, L.O.; Jewell, A.M.; Dawson, B.C.; Haq, T.R.; Piedra, P.A. Gene sequence variability of the three surface proteins of Human Respiratory Syncytial Virus (HRSV) in Texas. PLoS ONE 2014, 9. [CrossRef] [PubMed]

17. Bashir, U.; Nisar, N.; Mahmood, N.; Alam, M.M.; Sadia, H.; Zaidi, S.S.Z. Molecular detection and characterization of respiratory syncytial virus B genotypes circulating in Pakistani children. Infect. Gen. Evol. 2017, 47, 125-131. [CrossRef] [PubMed]

18. Otieno, J.R.; Kamau, E.M.; Agoti, C.N.; Lewa, C.; Otieno, G.; Bett, A.; Ngama, M.; Cane, P.A.; Nokes, D.J. Spread and Evolution of Respiratory Syncytial Virus A Genotype ON1, Coastal Kenya, 2010-2015. Emerg. Infect. Dis. 2017, 23, 264-271. [CrossRef] [PubMed]

19. Duvvuri, V.R.; Granados, A.; Rosenfeld, P.; Bahl, J.; Eshaghi, A.; Gubbay, J.B. Genetic diversity and evolutionary insights of respiratory syncytial virus A ON1 genotype: Global and local transmission dynamics. Sci. Rep. 2015, 5, 14268. [CrossRef] [PubMed]

20. Ahmed, A.; Haider, S.H.; Parveen, S.; Arshad, M.; Alsenaidy, H.A.; Baaboud, A.O.; Mobaireek, K.F.; AlSaadi, M.M.; Alsenaidy, A.M.; Sullender, W. Co-circulation of 72 bp duplication group A and $60 \mathrm{bp}$ duplication group B respiratory syncytial virus (RSV) strains in Riyadh, Saudi Arabia during 2014. PLoS ONE 2016, 11. [CrossRef] [PubMed]

21. Trento, A.; Galiano, M.; Videla, C.; Carballal, G.; Garcia-Barreno, B.; Melero, J.A.; Palomo, C. Major changes in the $\mathrm{G}$ protein of human respiratory syncytial virus isolates introduced by a duplication of 60 nucleotides. J. Gen. Virol. 2003, 84, 3115-3120. [CrossRef] [PubMed]

22. Trento, A.; Casas, I.; Calderón, A.; Garcia-Garcia, M.L.; Calvo, C.; Perez-Breña, P.; Melero, J.A. Ten years of global evolution of the human respiratory syncytial virus BA genotype with a 60-nucleotide duplication in the G protein gene. J. Virol. 2010, 84, 7500-7512. [CrossRef] [PubMed]

23. Dapat, I.C.; Shobugawa, Y.; Sano, Y.; Saito, R.; Sasaki, A.; Suzuki, Y.; Kumaki, A.; Zaraket, H.; Dapat, C.; Oguma, T.; et al. New genotypes within respiratory syncytial virus group B genotype BA in Niigata, Japan. J. Clin. Microbiol. 2010, 48, 3423-3427. [CrossRef] [PubMed]

24. Luchsinger, V.; Ampuero, S.; Palomino, M.A.; Chnaiderman, J.; Levican, J.; Gaggero, A.; Larrañaga, C.E. Comparison of virological profiles of respiratory syncytial virus and rhinovirus in acute lower tract respiratory infections in very young Chilean infants, according to their clinical outcome. J. Clin. Virol. 2014, 61, 138-144. [CrossRef] [PubMed]

25. Esposito, S.; Piralla, A.; Zampiero, A.; Bianchini, S.; Di Pietro, G.; Scala, A.; Pinzani, R.; Fossali, E.; Baldanti, F.; Principi, N. Characteristics and their clinical relevance of respiratory syncytial virus types and genotypes circulating in Northern Italy in five consecutive winter seasons. PLoS ONE 2015, 10, e0129369. [CrossRef] [PubMed]

26. Yoshihara, K.; Le, M.N.; Okamoto, M.; Carolle, A.; Wadagni, A. Association of RSV-A ON1 genotype with Increased Pediatric Acute Lower Respiratory Tract Infection in Vietnam. Sci. Rep. 2016, 6, 1-10. [CrossRef] [PubMed]

27. Buckingham, S.C.; Bush, A.J.; Devincenzo, J.P. Nasal quantity of respiratory syncytical virus correlates with disease severity in hospitalized infants. Pediatr. Infect. Dis. J. 2000, 19, 113-117. [CrossRef] [PubMed]

28. Scagnolari, C.; Midulla, F.; Selvaggi, C.; Monteleone, K.; Bonci, E.; Papoff, P.; Cangiano, G.; Di Marco, P.; Moretti, C.; Pierangeli, A.; et al. Evaluation of viral load in infants hospitalized with bronchiolitis caused by respiratory syncytial virus. Med. Microbiol. Immunol. 2012, 201, 311-317. [CrossRef] [PubMed]

29. DeVincenzo, J.P.; El Saleeby, C.M.; Bush, A.J. Respiratory syncytial virus load predicts disease severity in previously healthy infants. J. Infect. Dis. 2005, 191, 1861-1868. [CrossRef] [PubMed] 
30. El Saleeby, C.M.; Bush, A.J.; Harrison, L.M.; Aitken, J.A.; DeVincenzo, J.P. Respiratory syncytial virus load, viral dynamics, and disease severity in previously healthy naturally infected children. J. Infect. Dis. 2011, 204, 996-1002. [CrossRef] [PubMed]

31. Hasegawa, K.; Jartti, T.; Mansbach, J.M.; Laham, F.R.; Jewell, A.M.; Espinola, J.A.; Piedra, P.A.; Camargo, C.A. Respiratory syncytial virus genomic load and disease severity among children hospitalized with bronchiolitis: Multicenter cohort studies in the United States and Finland. J. Infect. Dis. 2015, 211, 1550-1559. [CrossRef] [PubMed]

32. Larrañaga, C.; Ampuero, S.; Luchsinger, V.; Carrión, F.; Aguilar, N.; Morales, P.; Palomino, M.A.; Tapia, L.; Avendaño, L.F. Impaired immune response in severe human lower tract respiratory infection by respiratory syncytial virus. Pediatr. Infect. Dis. J. 2009, 28, 867-873. [CrossRef] [PubMed]

33. DeVincenzo, J.P.; McClure, M.W.; Symons, J.A.; Fathi, H.; Westland, C.; Chanda, S.; Lambkin-Williams, R.; Smith, P.; Zhang, Q.; Beigelman, L.; et al. Activity of Oral ALS-008176 in a Respiratory Syncytial Virus Challenge Study. N. Engl. J. Med. 2015, 373, 2048-2058. [CrossRef] [PubMed]

34. DeVincenzo, J.P.; Whitley, R.J.; Mackman, R.L.; Scaglioni-Weinlich, C.; Harrison, L.; Farrell, E.; McBride, S.; Lambkin-Williams, R.; Jordan, R.; Xin, Y.; et al. Oral GS-5806 activity in a respiratory syncytial virus challenge study. N. Engl. J. Med. 2014, 371, 711-722. [CrossRef] [PubMed]

35. Instituto de Salud Pública de Chile. Available online: http://www.ispch.cl/virusrespiratorios (accessed on 16 March 2017).

36. Melero, J.A.; Mas, V. The Pneumovirinae fusion (F) protein: A common target for vaccines and antivirals. Virus Res. 2015, 209, 128-135. [CrossRef] [PubMed]

37. Mansbach, J.M.; Piedra, P.A.; Teach, S.J.; Sullivan, A.F.; Forgey, T.; Clark, S.; Espinola, J.A.; Camargo, C.A. Prospective multicenter study of viral etiology and hospital length of stay in children with severe bronchiolitis. Arch. Pediatr. Adolesc. Med. 2012, 166, 700-706. [PubMed]

38. Jartti, T.; Lehtinen, P.; Vuorinen, T.; Ruuskanen, O. Bronchiolitis: Age and previous wheezing episodes are linked to viral etiology and atopic characteristics. Pediatr. Infect. Dis. J. 2009, 28, 311-317. [CrossRef] [PubMed]

39. Mansbach, J.M.; Clark, S.; Teach, S.J.; Gern, J.E.; Piedra, P.A.; Sullivan, A.F.; Espinola, J.A.; Camargo, C.A. Children Hospitalized with Rhinovirus Bronchiolitis Have Asthma-Like Characteristics. J. Pediatr. 2016, 172, 202-204. [CrossRef] [PubMed]

40. Houben, M.L.; Coenjaerts, F.E.; Rossen, J.W.; Belderbos, M.E.; Hofland, R.W.; Kimpen, J.L.L.; Bont, L.J. Disease severity and viral load are correlated in infants with primary respiratory syncytial virus infection in the community. J. Med. Virol. 2010, 82, 1266-1271. [CrossRef] [PubMed]

41. Zhou, L.; Xiao, Q.; Zhao, Y.; Huang, A.; Ren, L.; Liu, E. The impact of viral dynamics on the clinical severity of infants with respiratory syncytial virus bronchiolitis. J. Med. Virol. 2015, 87, 1276-1284. [CrossRef] [PubMed]

42. Beckham, J.D.; Cadena, A.; Lin, J.; Piedra, P.A.; Glezen, W.P.; Greenberg, S.B.; Atmar, R.L. Respiratory viral infections in patients with chronic, obstructive pulmonary disease. J. Infect. 2005, 50, 322-330. [CrossRef] [PubMed]

43. Knorr, L.; Fox, J.D.; Tilley, P.A.G.; Ahmed-Bentley, J. Evaluation of real-time PCR for diagnosis of Bordetella pertussis infection. BMC Infect. Dis. 2006, 6, 1-12. [CrossRef] [PubMed]

44. Winchell, J.M.; Thurman, K.A.; Mitchell, S.L.; Thacker, W.L.; Fields, B.S. Evaluation of three real-time PCR assays for detection of Mycoplasma pneumoniae in an outbreak investigation. J. Clin. Microbiol. 2008, 46, 3116-3118. [CrossRef] [PubMed]

45. Do, L.A.H.; van Doorn, H.R.; Bryant, J.E.; Nghiem, M.N.; Nguyen Van, V.C.; Vo, C.K.; Nguyen, M.D.; Tran, T.H.; Farrar, J.; De Jong, M.D. A sensitive real-time PCR for detection and subgrouping of human respiratory syncytial virus. J. Virol. Methods 2012, 179, 250-255. [CrossRef] [PubMed]

46. Hall, T.A. BioEdit: A user-friendly biological sequence alignment editor and analysis program for Windows 95/98/NT. Nucleic Acids Symp. Ser. 1999, 41, 95-98.

47. Zlateva, K.T.; Lemey, P.; Vandamme, A.; Ranst, M. Van Molecular Evolution and Circulation Patterns of Human Respiratory Syncytial Virus Subgroup A: Positively Selected Sites in the Attachment G Glycoprotein. J. Virol. 2004, 78, 4675-4683. [CrossRef] [PubMed] 
48. García, O.; Martín, M.; Dopazo, J.; Arbiza, J.; Frabasile, S.; Russi, J.; Hortal, M.; Perez-Breña, P.; Martínez, I.; García-Barreno, B.; et al. Evolutionary pattern of human respiratory syncytial virus (subgroup A): Cocirculating lineages and correlation of genetic and antigenic changes in the G glycoprotein. J. Virol. 1994, 68, 5448-5459. [PubMed]

49. Rebuffo-Scheer, C.; Bose, M.; He, J.; Khaja, S.; Ulatowski, M.; Beck, E.T.; Fan, J.; Kumar, S.; Nelson, M.I.; Henrickson, K.J. Whole Genome Sequencing and Evolutionary Analysis of Human Respiratory Syncytial Virus A and B from Milwaukee, WI 1998-2010. PLoS ONE 2011, 6, e25468. [CrossRef] [PubMed]

(C) 2017 by the authors. Licensee MDPI, Basel, Switzerland. This article is an open access article distributed under the terms and conditions of the Creative Commons Attribution (CC BY) license (http:/ / creativecommons.org/licenses/by/4.0/). 